The International Journal of Banking and Finance, Volume 9 (Number 3) 2012: pages 72-87

\title{
PERFORMANCE OF CHINA-OWNED BANKS IN HONG KONG
}

\author{
Xiaoxi Zhang and Kevin Daly \\ University of Western Sydney, Australia
}

\begin{abstract}
This paper reports results on the performance of mainland China-owned banks operating in Hong Kong and compares them to Hong Kong (SAR) owned banks and Foreign owned banks. In general, the test model performs well under diagnostic tests on variables such as net interest margin, non-interest expense, impaired loans ratio, equity multiplier and ownership structures. Profitability, as measured by return on assets and return on equity for Chinese owned banks increased over the period 2004-2010. Chinese owned banks recorded increased performance in terms of net interest margin and equity multiplier but decreased with respect to non-interest expense and impaired loans ratio. Banks having a license also appears to be a major contributor to banks profitability across HKSAR. Compared to Hong Kong based foreign banks and local Hong Kong banks, we found that in general the mainland China banks tend to perform poorly across a number of key banking performance indicators.
\end{abstract}

Key Words: Bank performance; China’s financial outward investment; Chinese banks in Hong Kong

JEL classification: G21, F21, F23

\section{Introduction}

This paper constructs a model of the profitability of China owned banks operating in Hong Kong (HK). Compared to other industries, China's outward investment across the financial sector represents a relatively small proportion of its total dollar investment abroad. However outward financial investment has being increasing gradually especially since 2006. To give an idea of this growth, shown in a figure at later page of this paper, we examine China's total outward financial investment over 2006- 2009. From the figure, it is clear that the growth in outward financial investments is almost entirely explained by financial investment to HK. 
Discovering the factors driving the outward investment in the area of finance should be as important as that of China's outward investment in manufacturing and resources sectors. The objective of this research is therefore to analyse the performance of China's banks with a particular focus on HK. By using firm level data across a range of performance indicators, this research enables researchers to discover the key determinants of China's outward investment in the banking sector.

Chinese owned banks comprise approximately twenty five percent of all foreign owned banking assets operating in Hong Kong. The presence of Chinese owned banks operating in HKSAR allows us to apply firm-specific data in particular parent-specific characteristics of Chinese banks performance in Hong Kong. In order to investigate this issue fully, we compared Chinese owned banks with two other groups’ namely local owned banks i.e. HKSAR and owned foreign banks.

The rest of the paper is structured as follows: section one provides an overview of foreign banks (including China's owned banks) operating in HKSAR; section two reviews previous studies conducted into measuring banks performance in HK including hypotheses testing; section three provides a description of the data sources and methodology; section five discusses the empirical results; the final section offers some concluding comments and provides some suggestion for Chinese bank expansion overseas in the future.

\section{Figure 1: Chinese Outward Investment in Financial Industry Stocks, total and in Hong} Kong, 2006-2009, \$100 million

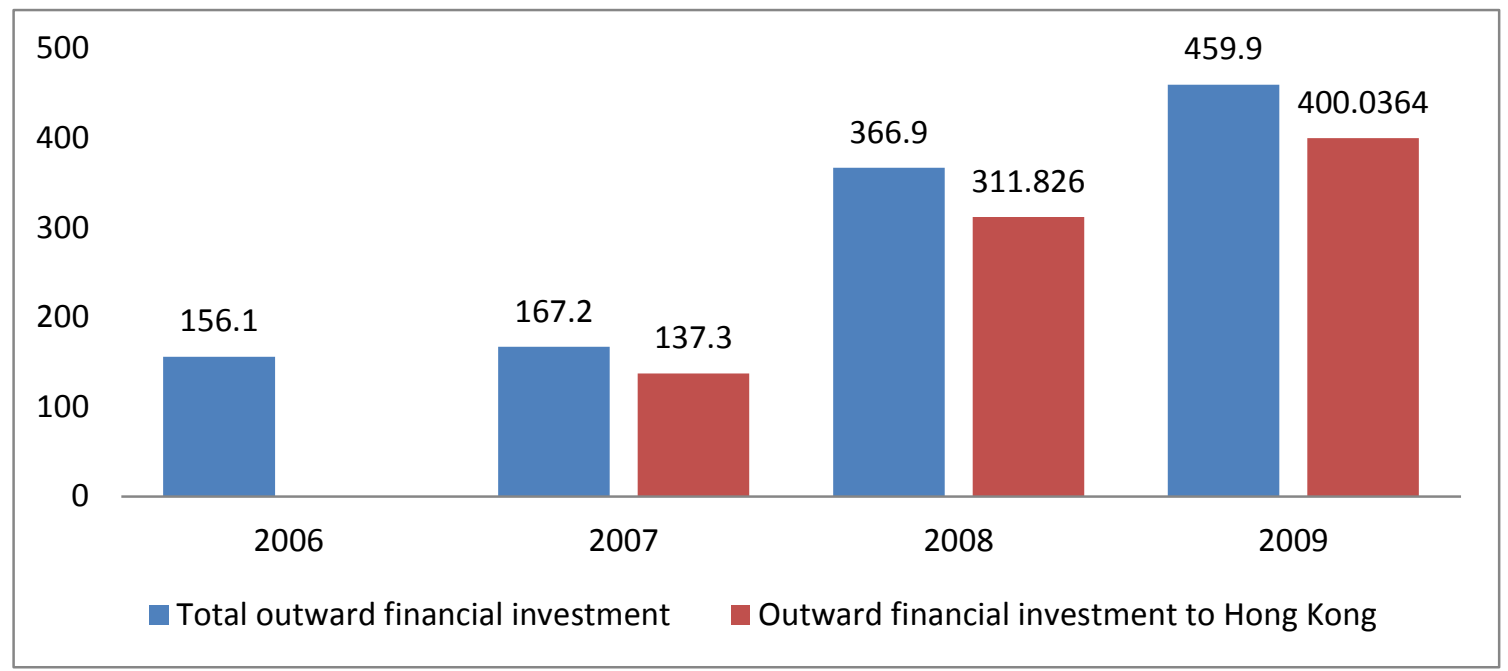

Source: Statistical Bulletin of China’s outward Foreign Direct Investment, 2006, 2007, 2008, 2009. 


\section{Foreign Banks in Hong Kong}

Hong Kong is one of the world's largest offshore banking centers, with approximately sixty of world's largest banks operating within the SAR of Hong Kong: see Table 1.

Table 1: Selected list of licensed banks incorporated in Hong Kong

\begin{tabular}{|c|c|c|}
\hline Name & Type & Country/Region \\
\hline Bank of China (Hong Kong) & Limited & China \\
\hline Bank of East Asia & Limited & Hong Kong \\
\hline China Construction Bank (Asia) & Corporation Limited & China \\
\hline Chiyu Banking Corporation & Limited & China \\
\hline Chong Hing Bank & Limited & Hong Kong \\
\hline Citibank (Hong Kong) & Limited & United States \\
\hline CITIC Ka Wah Bank & Limited & China \\
\hline Dah Sing Bank & Limited & Hong Kong \\
\hline DBS Bank (Hong Kong) & Limited & Singapore \\
\hline Fubon Bank (Hong Kong) & Limited & Taiwan \\
\hline Hang Seng Bank & Limited & Hong Kong \\
\hline Hongkong and Shanghai Banking Corporation & Limited & United Kingdom \\
\hline Industrial and Commercial Bank of China (Asia) & Limited & China \\
\hline MEVAS Bank & Limited & Hong Kong \\
\hline Nanyang Commercial Bank & Limited & China \\
\hline Public Bank (Hong Kong) & Limited & Malaysia \\
\hline Shanghai Commercial Bank & Limited & Hong Kong \\
\hline Standard Chartered Bank (Hong Kong) & Limited & United Kingdom \\
\hline Tai Sang Bank & Limited & Hong Kong \\
\hline Tai Yau Bank & Limited & Hong Kong \\
\hline Wing Hang Bank & Limited & Hong Kong \\
\hline Wing Lung Bank & Limited & China \\
\hline
\end{tabular}

Source: The Financial Services Sector in Hong Kong, Hong Kong Monthly Digest of Statistics.

Traditionally Hong Kong has been acknowledged globally as having a strong, independent and stable banking system, in addition the HK dollar has over time been recognized as a stable managed currency, the HK economic model is viewed by foreigners as somewhat more liberal than that of mainland China, in addition HK administers a lower taxation regime relative to most developed economies, taken together these characteristics make $\mathrm{HK}$ an attractive financial investment destination for multinational banks.. Hong Kong as an offshore banking center 
operates a three-tier banking system that includes licensed banks; ${ }^{1}$ restricted license banks $(\mathrm{RLBs})^{2}$ and deposit-taking companies (DTCs). ${ }^{3}$ This three-tier banking system allows Hong Kong authorities to keep domestic and offshore banking sectors separate from each other. Foreign banks which do not qualify for a full bank license usually get RLB or DTC license status which allows them to conduct wholesale and investment banking business on the Asian Dollar Market.

In 2005 Hong Kong was host to 133 incorporated licensed banks, 39 restricted license banks and 35 deposit-taking companies in addition of the 207 authorized institutions 182 were foreign owned.

\section{Hypotheses and Tests}

This research employs firm-level panel data to examine several performance specific hypotheses. As acknowledge relatively few studies employ industry-level data to test other countries' financial institutions performance in a third country. The data considered in this study employs Chinese, Foreign and Hong Kong owned banks in Hong Kong from 2004 to 2010, separately. This paper takes into account institutional features such as expenses management, capital liquidity and firm’s ownership.

\section{Profitability measures}

The profitability of banks operating across borders can be measured by several variables. This study will consider the following dimensions; Return on Assets (ROA) and Return on Equities (ROE): the ROA is used to measure earning ability which is net income after taxes for the year relative to total average assets. ROA is an internal performance measure of shareholder value, and it is by far the most popular measure of performance because: (1) it proposes a direct assessment of the financial return of a shareholder's investment; (2) it is easily available for analysts, only relying upon public information; and (3) it allows for comparison between different companies or different sectors of the economy. The Return on Equity (ROE) is used to measure bank's profitability which is net income after taxes divided by total equity. However, ROA is biased upwards for banks that earn significant profits from off-balance sheet operations

\footnotetext{
${ }^{1}$ They can accept deposits of any size and maturity. They are also allowed to provide current and savings accounts to their clients.

2 They are allowed to accept deposits of HK\$500,000 and above.

${ }^{3}$ They are licensed to accept deposits of HK\$100,000 and above with the minimum maturity of 3 months.
} 
such as derivative activities, as these activities generate revenue and expenses but are not recorded as assets (Rhoades, 1998). Therefore, we employ ROE as an alternative measure of profitability.

\section{Hypotheses}

In the context, of factors within the control of management the immediate factors, which would have an impact on bank profitability, would be those factors, which affect a bank's net interest income (Guru, et al, 2000). To this extent, the net interest margin could be expected to have a positive influence on bank’s profitability.

Hypothesis 1: net interest margin has a positive impact on profitability in Hong Kong

Generally, bank's efficiency regards cost control would be reflected in profit. A Federal Reserve Bank of New York study found that enhanced expenses such as salaries and wages, pensions, and other (non-interest) expenses resulted in relatively slower growth in profitability (Federal Reserve Bank of New York 1973, pp. 70-71).

Hypothesis 2: non-interest expense has a negative impact on profitability in Hong Kong

Licensed banks are expected to have some positive value; otherwise no institution would be willing to bear the regulatory costs associated with gaining a licence. Previous research has indicated that foreign banks expressed a strong preference for banking licence status upon entering into a foreign market, Davis \& Lewis (1982). Thus a bank licence may be considered as a firm-specific advantage. In our model a bank licence is treated as an exogenous variable, as the Chinese banks applied for a bank licence, but the decision as to their success or failure was outside their control.

Hypothesis 3: The possession of a bank license has a positive impact on profitability in Hong Kong.

The ratio of impaired loans to gross loans (NPL) is included to capture the effect of credit risk on bank profitability. Evidence suggests that impaired loans may increase after periods of increased lending often when senior bank managers under competitive pressure to satisfy shortterm profit targets imposed by owners employ less rigorous lending standards (Salas and Saurina, 2002; Berger and Udell, 2006; Ruckes, 2004). Petersen \& Rajan (1994) posited that banks concerned for short-run reputation will ease credit standards to boost assets growth and profitability in order to maintain comparability with peer banks. Furthermore, disaster myopia 
may occur when banks find it difficult to acknowledge and assess the possibility of a major shock to their loan books (Guttentag and Herring, 1986; Herring, 1999). Consequently, decisions are based on recent information, which is assumed to continue into the future. This myopia may be accompanied by overconfidence (where bank managers believe in their investing skills), which lead them to undertake excessive lending and risk leading to increases in impaired loans in the longer term. Overall, we expect a negative relationship between NPL and profitability.

Hypothesis 4: impaired loans ratio has a negative impact on profitability in Hong Kong

The equity multiplier (defined as assets divided by equity) is the reciprocal of the capital-toasset ratio. It provides a gauge of bank's leverage (debt-to-asset ratio), or the dollar amount of assets pyramided on the bank's base of equity capital. A higher EM indicates that the bank has borrowed more funds to convert into asset with the share capital. The higher value of EM indicates greater risk for a bank. Samad and Hassan (2000) found that the higher returns might have been due to higher risky investments by the bank. This is supported by the increased debt equity and equity multiplier ratio.

Hypothesis 5: equity multiplier has a positive impact on profitability in Hong Kong.

\section{Data and Methodology}

This research considers the period from 2004 to 2010, the data was provided by BankScope, the Hong Kong Monetary Authority and the Chinese Financial Yearbooks. We cannot obtain earlier data because most data in these databases started from 2004.

The general consensus from the literature regards modelling bank profitability favours a linear analysis approach. To this extent, Short (1979) and Bourke (1989) considered several functional forms and concluded that the linear model produced results as good as any other functional form. In support of this, Molyneux et al, (1994) and Guru, et al, (2000) had also considered a linear model in their studies on bank profitability. Thus, in this study as well we have considered a linear model to analyse pooled cross-section time series data.

Our modelling begins with running four regressions simultaneously, using return on assets (ROA) and return on equity (ROE) as dependent variables we itemised our independent variables as net interest margin (MARGIN), non-interest expense (NIE) and the ratio of impaired loans to gross loans (NPL). Net interest margin is a measure of the difference between the interest 
income generated by banks and the amount of interest paid out to their lenders (for example, deposits), relative to the amount of their (interest-earning) assets. Based on the definition, we expect there is a positive relationship between profitability and net interest margin if the ratio is bigger the ROA and ROE should be larger. Theoretically, higher non-interest expense (including employee salaries and benefits, equipment and property leases, taxes, loan loss provisions and professional service fees) will reduce bank profitability which is showed by ROA and ROE in our study. Impaired loans ration represents banks' loan quality, we expect it has a negative effect on ROA and ROE.

Our initial empirical model considered seven of China's largest owned banks operating in Hong Kong (Table 2). Since licensed banks in Hong Kong can accept deposits of any size and maturity we also separated our banks into licensed/non-licensed groups to find if having a license can be an advantage to bank performance. Next, we compared Chinese owned banks with two other groups namely: Hong Kong locally owned banks and foreign (other countries except China) owned banks. Finally we ran a regression employing our enlarged sample of banks which included the top 30 banks (nine Chinese owned banks, nine local owned banks and eleven foreign owned banks) in Hong Kong (Table 3). In this regression we added one more independent variable s called Equity Multiplier (EM) ${ }^{4}$ to carry out regression.

Table 2: Top 7 China's owned banks in Hong Kong

\begin{tabular}{|c|c|c|c|}
\hline Bank name & $\begin{array}{l}\text { Licensed/U } \\
\text { nlicensed }\end{array}$ & Chinese shareholder name & $\begin{array}{l}\text { Latest total assets } \\
\text { (Mil HKD) }\end{array}$ \\
\hline CITIC Bank & Licensed & CHINA CITIC BANK & 148,209 \\
\hline International Limited & & CORPORATION LIMITED & \\
\hline Wing Lung Bank Ltd & Licensed & $\begin{array}{l}\text { CHINA MERCHANTS } \\
\text { BANK CO LTD }\end{array}$ & 137,075 \\
\hline $\begin{array}{l}\text { China Construction Bank } \\
\text { (Asia) Corporation } \\
\text { Limited }\end{array}$ & Licensed & $\begin{array}{l}\text { CHINA CONSTRUCTION } \\
\text { BANK CORPORATION }\end{array}$ & 102,728 \\
\hline $\begin{array}{l}\text { Industrial and } \\
\text { Commercial Bank of } \\
\text { China (Asia) Limited - } \\
\text { ICBC (Asia) }\end{array}$ & Licensed & $\begin{array}{l}\text { INDUSTRIAL \& } \\
\text { COMMERCIAL BANK OF } \\
\text { CHINA (THE) - ICBC }\end{array}$ & 266,939 \\
\hline $\begin{array}{l}\text { BOC Hong Kong } \\
\text { (Holdings) Ltd }\end{array}$ & Unlicensed & & $1,661,040$ \\
\hline $\begin{array}{l}\text { Bank of China (Hong } \\
\text { Kong) Limited }\end{array}$ & Licensed & $\begin{array}{l}\text { BANK OF CHINA } \\
\text { LIMITED }\end{array}$ & $1,612,194$ \\
\hline $\begin{array}{l}\text { Nanyang Commercial } \\
\text { Bank Ltd }\end{array}$ & Licensed & & 192,175 \\
\hline
\end{tabular}


Table 3: Top 30 banks in Hong Kong according to total assets

\begin{tabular}{|c|c|c|c|}
\hline Ranking & Bank name & Country/Region & $\begin{array}{l}\text { Latest total } \\
\text { assets (Mil } \\
\text { HKD) }\end{array}$ \\
\hline 1 & $\begin{array}{l}\text { Hong Kong and Shanghai Banking Corporation } \\
\text { Limited }\end{array}$ & GB & $5,039,918$ \\
\hline 2 & Bank of China (Hong Kong) Limited & $\mathrm{CN}$ & $1,612,194$ \\
\hline 3 & Hang Seng Bank Ltd. & GB & 916,911 \\
\hline 4 & Standard Chartered Bank (Hong Kong) Limited & GB & 758,555 \\
\hline 5 & Bank of East Asia Ltd & HK & 534,193 \\
\hline 6 & $\begin{array}{l}\text { Industrial and Commercial Bank of China } \\
\text { (Asia) Limited }\end{array}$ & $\mathrm{CN}$ & 266,939 \\
\hline 7 & DBS Bank (Hong Kong) Limited & SG & 247,423 \\
\hline 8 & Nanyang Commercial Bank Ltd & $\mathrm{CN}$ & 192,175 \\
\hline 9 & Wing Hang Bank Ltd & HK & 159,297 \\
\hline 10 & CITIC Bank International Limited & $\mathrm{CN}$ & 148,209 \\
\hline 11 & Wing Lung Bank Ltd & $\mathrm{CN}$ & 137,075 \\
\hline 12 & Dah Sing Bank, Ltd & HK & 130,509 \\
\hline 13 & Citibank (Hong Kong) Limited & US & 119,299 \\
\hline 14 & Shanghai Commercial Bank Ltd & TW & 118,642 \\
\hline 15 & $\begin{array}{l}\text { China Construction Bank (Asia) Corporation } \\
\text { Limited }\end{array}$ & $\mathrm{CN}$ & 102,728 \\
\hline 16 & Chong Hing Bank Limited & HK & 74,289 \\
\hline 17 & Fubon Bank (Hong Kong) Limited & TW & 61,780 \\
\hline 18 & Hong Kong Mortgage Corporation Limited & HK & 55033 \\
\hline 19 & Chiyu Banking Corporation Ltd. & $\mathrm{CN}$ & 41,067 \\
\hline 20 & Public Bank (Hong Kong) Limited & $\mathrm{BM}$ & 36,848 \\
\hline 21 & China Everbright Limited & HK & 33,942 \\
\hline 22 & Sun Hung Kai \& Co. Limited & HK & 20,151 \\
\hline 23 & BOCI Securities Limited & $\mathrm{CN}$ & 11,502 \\
\hline 24 & Daiwa Capital Markets Investments Asia & HK & 1,481 \\
\hline 25 & $\begin{array}{l}\text { China Construction Bank (Asia) Finance } \\
\text { Limited }\end{array}$ & $\mathrm{CN}$ & 6,175 \\
\hline 26 & China Merchants Securities (HK) Co.Ltd & $\mathrm{CN}$ & 5,011 \\
\hline 27 & Kookmin Bank Hong Kong Limited & KR & 608 \\
\hline 28 & Standard Bank Asia Limited & $\mathrm{ZA}$ & 457 \\
\hline 29 & Sun Hung Kai Investment Services Limited & HK & 3,340 \\
\hline 30 & Orix Asia Limited & JP & 409 \\
\hline
\end{tabular}

The basic regression model takes the form with parameters $(\gamma, \alpha, \beta s)$ and error terms $(\mu, \varepsilon)$ :

Bank Performance Measure $=\gamma+\beta_{1}($ MARGIN $)+\beta_{2}(N I E)+\beta_{3}(N P L)+\mu$

Bank Performance Measure $=\alpha+\beta_{1}(M A R G I N)+\beta_{2}(N I E)+\beta_{3}(N P L)+\beta_{4}(A E)+\varepsilon$

The variables specified as following with time subscript not shown: 


\section{Dependent variables}

ROA : profits after tax / total average assets,

ROE : profits after tax / total average equity,

Independent variables

MARGIN : (interest income - interest payment) / interest-earning assets,

NIE : non-interest expense/ total average assets,

NPL : impaired loans (NPLs) / gross loans, and

EM : total assets / total equity.

In this study, all regression equations were estimated using pooled time series crosssection (TSCS) data in order to use the information in the data set.

\section{Empirical Results}

Table 4 presents the regression results for the major seven Chinese owned banks operating in Hong Kong from 2004 to 2010. Rows (1-7) provide an indication of the effect of net interest margin on ROA and ROE for each bank. For example, in Row one (CITIC) banks results from the regression of net interest margin on ROA and ROE are provided. These results indicate that ROA and ROE are positively related to MARGIN but only significant for Wing Lung Bank (WL) and Nanyang Commercial Bank (NY). Interestingly row seven (NIE) indicates the relationship between non-interest expense and ROA and ROE. The result here indicates that in almost one hundred percent of cases, WL's NIE reduces its return on assets while non interest expenses are also highly significant and negatively related to the Bank's return on equity. However, for other banks this effect is insignificant and positive (except Nanyang Commercial Bank which is showed a negative relation). The last seven rows indicate that negative and significant relationship appears for impaired loans and ROA in the case of WL, and negative and significant in the case of CITIC bank.

When we examine the results from Table 5 we conclude the following: overall the results for MARGIN indicate that net interest margin has a significant and positive relationship with ROA and ROE for two banks. Our results suggest that licensed banks are more profitable than unlicensed banks. For example, when net interest margin increases by 1\%, licensed banks can 
Table 4: Top 7 Chinese owned banks performance in Hong Kong, 2004-2010

\begin{tabular}{|c|c|c|c|}
\hline \multicolumn{2}{|c|}{ Dependent Variable } & ROA & $\mathrm{ROE}$ \\
\hline \multicolumn{4}{|c|}{ Independent Variables } \\
\hline \multirow{14}{*}{ Margin } & \multirow[t]{2}{*}{ CITIC } & 0.789763 & 11.6889 \\
\hline & & $(0.5026)$ & $(0.3398)$ \\
\hline & \multirow[t]{2}{*}{ WL } & 2.155831 & 14.8658 \\
\hline & & $(0.0024)^{* * *}$ & $(0.0323)^{* *}$ \\
\hline & \multirow[t]{2}{*}{ CCB } & 0.40550 & 2.06029 \\
\hline & & $(0.2150)$ & $(0.5369)$ \\
\hline & \multirow[t]{2}{*}{$\mathrm{BOCH}$} & 0.21412 & 2.52278 \\
\hline & & $(0.7858)$ & $(0.7569)$ \\
\hline & \multirow[t]{2}{*}{ BOC } & 0.89406 & 10.7575 \\
\hline & & $(0.5431)$ & $(0.4798)$ \\
\hline & \multirow{2}{*}{ NY } & 0.96444 & 7.58278 \\
\hline & & $(0.0161)^{* *}$ & $(0.0601)^{*}$ \\
\hline & \multirow[t]{2}{*}{ ICBC } & 0.51584 & 7.74798 \\
\hline & & $(0.4993)$ & $(0.3292)$ \\
\hline \multirow{14}{*}{ NIE } & \multirow[t]{2}{*}{ CITIC } & 1.04061 & 13.1931 \\
\hline & & $(0.3904)$ & $(0.2943)$ \\
\hline & \multirow[t]{2}{*}{ WL } & -3.36211 & -23.6044 \\
\hline & & $(0.0024) * * *$ & $(0.0093)^{* *}$ \\
\hline & \multirow[t]{2}{*}{ ССВ } & 0.17781 & 1.29047 \\
\hline & & $(0.8058)$ & $(0.8630)$ \\
\hline & \multirow[t]{2}{*}{$\mathrm{BOCH}$} & 0.87243 & 12.9179 \\
\hline & & $(0.5165)$ & $(0.3553)$ \\
\hline & \multirow[t]{2}{*}{ BOC } & 3.24912 & 43.5914 \\
\hline & & $(0.3304)$ & $(0.2100)$ \\
\hline & \multirow[t]{2}{*}{ NY } & -0.71437 & -5.80317 \\
\hline & & $(0.3586)$ & $(0.4691)$ \\
\hline & \multirow[t]{2}{*}{ ICBC } & 0.07584 & 1.96536 \\
\hline & & $(0.9750)$ & $(0.9374)$ \\
\hline \multirow{14}{*}{ NPL } & \multirow[t]{2}{*}{ CITIC } & -0.36246 & -5.72297 \\
\hline & & $(0.3502)$ & $(0.0591)^{*}$ \\
\hline & \multirow[t]{2}{*}{ WL } & -1.33174 & 12.9012 \\
\hline & & $(0.0442)^{* *}$ & $(0.1700)$ \\
\hline & \multirow[t]{2}{*}{ CCB } & -0.09124 & 0.52723 \\
\hline & & $(0.9661)$ & $(0.9810)$ \\
\hline & \multirow[t]{2}{*}{$\mathrm{BOCH}$} & 0.00320 & -6.61851 \\
\hline & & (0.9987) & $(0.7499)$ \\
\hline & \multirow[t]{2}{*}{ BOC } & 1.35090 & 8.84538 \\
\hline & & $(0.3912)$ & $(0.5852)$ \\
\hline & \multirow[t]{2}{*}{$\mathrm{NY}$} & 0.24533 & 2.53301 \\
\hline & & $(0.5532)$ & $(0.5537)$ \\
\hline & ICBC & 0.18541 & 2.55833 \\
\hline & & $(0.8682)$ & $(0.8248)$ \\
\hline
\end{tabular}




\begin{tabular}{ccc}
$\begin{array}{c}\text { Adjusted } \\
\text { R-squared }\end{array}$ & 0.61150 & 0.59241 \\
\hline Notes: $* * *$ and $* * *$ denote significance at 0.10, & 0.05 and 0.01 levels, respectively.
\end{tabular}

increase (ROA) by 0.53305 per cent and (ROE) by 15.0740 per cent while unlicensed banks returns are 0.21412 per cent (ROA) and 2.3734 per cent (ROE) respectively. We also found a positive relationship between NIE and profitability (ROA and ROE), but the results are only significant for ROE in the case of licensed banks. For NPL and ROA, the results are significant and positive for unlicensed banks (0.9989). Related to ROA, an increase of 1 per cent in NPL will cause ROE to decline by 2.0610 per cent for licensed banks and $1.001196 \%$ for unlicensed banks.

Table 5: Licensed/Unlicensed China-owned bank performance in Hong Kong, 2004-2010

\begin{tabular}{llll}
\hline \multirow{2}{*}{ MARGIN } & & ROA & ROE \\
& Licensed & 0.53305 & 15.0740 \\
& & $(0.0978)^{*}$ & $(0.0800)^{*}$ \\
NIE & Unlicensed & 0.21412 & 2.37346 \\
& & $(0.0819)^{*}$ & $(0.0922)^{*}$ \\
& Licensed & 0.21598 & 1.70692 \\
NPL & & $(0.8362)$ & $(0.0254)^{* *}$ \\
& Unlicensed & 0.87243 & 1.23015 \\
& & $(0.5934)$ & $(0.8413)$ \\
& Licensed & 0.20962 & -2.06108 \\
& & $(0.0799)^{*}$ & $(0.0355)^{* *}$ \\
Adjusted R-squared & Unlicensed & 0.9989 & -1.00119 \\
\hline
\end{tabular}

Notes: *,** and *** denote significance at $0.10,0.05$ and 0.01 levels, respectively.

The statistics in Table 6 indicates the results for HK's top 15 banks over 2004-2010. In terms of the relationship between net interest margin and profitability the results appear to be mixed across Chinese owned banks. MARGIN on Bank of China (Hong Kong) and CITIC bank is associated with a negative sign but insignificant relationship for ROA and ROE while for the other two bank groups this effect is positive. Regards NIE and profitability we found the results ambiguous. For example, the highly significant and negative relationship appears for NIE and ROA in the case of Wing Lung Bank (-3.3572) and Bank of East Asia (-1.7503) while for Hong Kong and Shanghai Banking Corporation this relationship is significantly positive (1.242263). Regards the results for NIE and ROE, we only found evidence for 5 significant results including 2 for Chinese owned banks (BOC and WLU), 2 for Hong Kong local banks (BOEA and WLA) 
Table 6: Top 15 bank performance in Hong Kong, 2004-2010

\begin{tabular}{|c|c|c|c|c|}
\hline Independeı & Variables & Dependent Variable & ROA & ROE \\
\hline & & BOC & -0.894061 & -10.75756 \\
\hline & & & $(0.4037)$ & $(0.3466)$ \\
\hline & & ICBC & 0.515843 & 7.747985 \\
\hline & & & $(0.3535)$ & $(0.1933)$ \\
\hline & & NY & 0.964440 & 7.582789 \\
\hline & & & $(0.0009)^{* * *}$ & $(0.0117)^{* *}$ \\
\hline & China & CITIC & -0.789763 & -11.68895 \\
\hline & & & $(0.3571)$ & $(0.2031)$ \\
\hline & & WLU & 2.152847 & 14.83528 \\
\hline & & & $(0.0000)^{* * *}$ & $(0.0041)^{* * *}$ \\
\hline & & $\mathrm{CCB}$ & 0.405504 & 2.060298 \\
\hline & & & $(0.0880)^{*}$ & $(0.4108)$ \\
\hline & & BOEA & 1.583841 & 16.67085 \\
\hline & & & $(0.0697)^{*}$ & $(0.0733)^{*}$ \\
\hline & Hong & WLA & 2.287652 & 30.64399 \\
\hline MARGIN & Kong & & $(0.0218)^{* *}$ & $(0.0045)^{* * *}$ \\
\hline & & DS & 0.639456 & 7.308102 \\
\hline & & & $(0.4257)$ & $(0.3936)$ \\
\hline & & HKSH & 0.310197 & 10.16891 \\
\hline & & & $(0.6563)$ & $(0.1751)$ \\
\hline & & HS & 1.612816 & 21.82092 \\
\hline & & & $(0.1606)$ & $(0.0769)^{*}$ \\
\hline & & $\mathrm{SC}$ & 0.945729 & 8.742491 \\
\hline & Foreiøn & & $(0.0435)^{* *}$ & $(0.0785)^{*}$ \\
\hline & Foreign & DBS & 0.720075 & 6.835456 \\
\hline & & & $(0.1323)$ & $(0.1793)$ \\
\hline & & CITI & 4.551043 & 4.234877 \\
\hline & & & $(0.1253)$ & $(0.0001)^{* * *}$ \\
\hline & & SCB & 0.648829 & 4.828662 \\
\hline & & & $(0.3288)$ & $(0.4945)$ \\
\hline & & $\mathrm{BOC}$ & 3.249124 & 1.707784 \\
\hline & & & $(0.1809)$ & $(0.0941)^{*}$ \\
\hline & & ICBC & 0.075847 & -1.965366 \\
\hline & & & $(0.9657)$ & $(0.9168)$ \\
\hline & & NY & -0.714374 & -5.803179 \\
\hline & China & & $(0.2070)$ & $(0.3348)$ \\
\hline & Cnina & CITIC & 1.040611 & 13.19317 \\
\hline NIE & & & $(0.2379)$ & $(0.1618)$ \\
\hline & & WLU & -3.357284 & -23.55725 \\
\hline & & & $(0.0000)^{* * *}$ & $(0.0034)^{* * *}$ \\
\hline & & CCB & 0.177811 & 1.290475 \\
\hline & & & $(0.7358)$ & $(0.8184)$ \\
\hline & & BOEA & -1.750362 & -16.82504 \\
\hline & $\begin{array}{l}\text { Hong } \\
\text { Kong }\end{array}$ & & $(0.0427)^{* *}$ & $(0.1856)$ \\
\hline & Kong & WLA & -2.862145 & -39.68585 \\
\hline
\end{tabular}




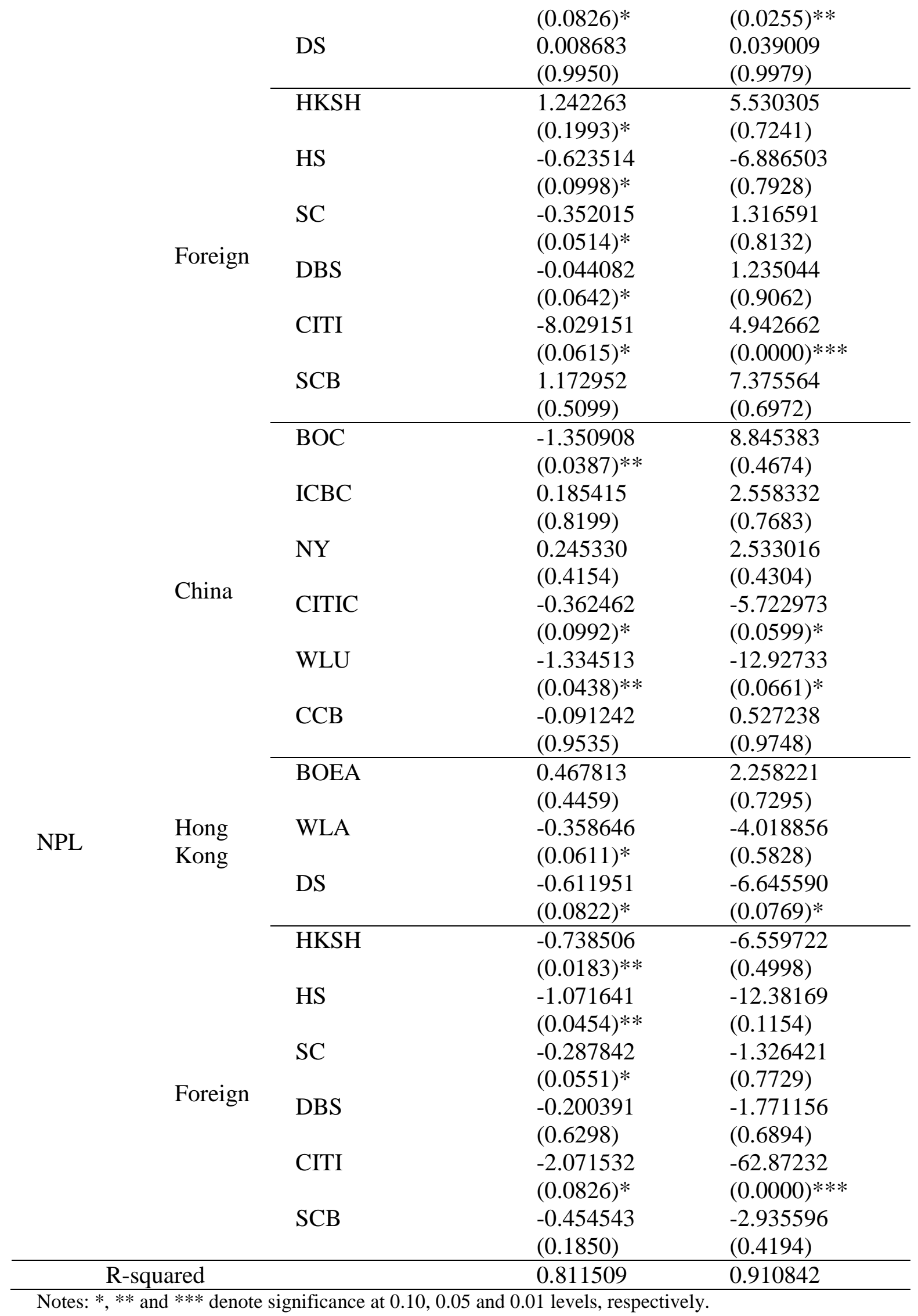


and 1 for a foreign owned bank (CITIC). In conclusion for these 5 banks we find the return on equity to increase along with non-interest expense for Bank of China and CITI bank, therefore BOC and CITI are less efficient than the other three banks due to higher ROE used and higher NIE. For example when we examine the results of CITI and WLA banks we find that a rise in non-interest expense by 1 per cent, causes ROE to increase by 4.9426 per cent, while for WLA ROE will increase by 39.6858 per cent if NIE decreases 1 per cent. The last fifteen rows suggest that a negative relationship exists between NPL and profitability.

Table 7: Top 30 bank Performance in Hong Kong by Groups, 2004-2010

\begin{tabular}{|c|c|c|c|}
\hline \multicolumn{2}{|l|}{ Dependent Variable } & \multirow[t]{2}{*}{ ROA } & \multirow[t]{2}{*}{$\mathrm{ROE}$} \\
\hline Independent Variab & & & \\
\hline \multirow{3}{*}{ MARGIN } & Chinese owned banks & $\begin{array}{l}0.75107 \\
(0.0676) *\end{array}$ & $\begin{array}{l}5.51634 \\
(0.3565)\end{array}$ \\
\hline & Hong Kong local banks & $\begin{array}{l}-0.16319 \\
(0.8510)\end{array}$ & $\begin{array}{l}0.61473 \\
(0.8603)\end{array}$ \\
\hline & Foreign owned banks & $\begin{array}{l}1.81734 \\
(0.0765)^{*}\end{array}$ & $\begin{array}{l}1.94773 \\
(0.9255)\end{array}$ \\
\hline \multirow{4}{*}{ NIE } & Chinese owned banks & $\begin{array}{l}-0.00866 \\
(0.9904)\end{array}$ & $\begin{array}{l}-0.6861 \\
(0.8134)\end{array}$ \\
\hline & Hong Kong local banks & $\begin{array}{l}1.16432 \\
(0.4573)\end{array}$ & $\begin{array}{l}-11.1892 \\
(0.0964)^{*}\end{array}$ \\
\hline & Foreign owned banks & $\begin{array}{l}-0.59615 \\
(0.5559)\end{array}$ & $\begin{array}{l}-3.35882 \\
(0.0436)^{* *}\end{array}$ \\
\hline & Chinese owned banks & $\begin{array}{l}-0.05875 \\
(0.0920)^{*}\end{array}$ & $\begin{array}{l}-1.17442 \\
(0.7654)\end{array}$ \\
\hline \multirow[t]{2}{*}{ NPL } & Hong Kong local banks & $\begin{array}{l}0.15767 \\
(0.8955)\end{array}$ & $\begin{array}{l}-15.1238 \\
(0.0104)^{* *}\end{array}$ \\
\hline & Foreign owned banks & $\begin{array}{l}-0.09840 \\
(0.9421)\end{array}$ & $\begin{array}{l}-2.13943 \\
(0.6958)\end{array}$ \\
\hline \multirow{3}{*}{ EM } & Chinese owned banks & $\begin{array}{l}-0.00191 \\
(0.9954)\end{array}$ & $\begin{array}{l}0.39581 \\
(0.0674)^{*}\end{array}$ \\
\hline & Hong Kong local banks & $\begin{array}{l}0.02214 \\
(0.8511)\end{array}$ & $\begin{array}{l}3.04913 \\
(0.0001)^{* * *}\end{array}$ \\
\hline & Foreign owned banks & $\begin{array}{l}-0.08582 \\
(0.9390)\end{array}$ & $\begin{array}{l}1.86858 \\
(0.0801)^{*}\end{array}$ \\
\hline \multicolumn{2}{|l|}{ Adjusted R-squar } & 0.5693 & 0.9013 \\
\hline
\end{tabular}

Notes: *, ** and ${ }^{* * *}$ denote significance at $0.10,0.05$ and 0.01 levels, respectively.

Table 7 examines the relationship between the top banks (30) performance indicators in HK against the profitability measures ROA and ROE. Rows (1-3) indicate that foreign owned banks will be more profitable on assets than Chinese owned banks if they charge the same 
percentage of net interest margin. Unfortunately, we cannot provide any indication of the effect of MARGIN on ROE in terms of insignificant results. Based on the results for NIE indicate that non-interest expense has a negative and significant relationship with ROE in local owned banks (-11.1892) and foreign owned banks (-3.3588) overall only one bank group here showed a significant result. Regards the results for bank equity multiplier and ROE we find a positive and significant relationship between EM and ROE in all cases for Chinese owned banks, and for Hong Kong owned banks and foreign owned banks.

\section{Conclusions}

In this study, we constructed a model of the profitability of Chinese owned banks in Hong Kong. Generally, the model proposed performs well for net interest margin, non-interest expense, and impaired loans ratio and equity multiplier. The purpose of this study was to evaluate how banking profitability in Hong Kong has been affected by these measures. Based on four regressions with annual data for the period from 2003-2010 our empirical results provide some interesting outcomes. The results indicate that for the top seven Chinese owned banks, Wing Lung Bank has superior recorded profits in terms of returns on assets and return on equity compared to other Chinese owned banks.

It is interesting to note that licensed Chinese owned banks will make more profits than unlicensed Chinese owned banks where both have similar net interest margin, management efficiency (non-interest expense) and asset's risk (impaired loans ratio). Comparing the top fifteen banks across our groupings (Chinese,HKSAR and Foreign), we found that in general Chinese banks tend to perform poorly in terms of MARGIN while profitability is ranked average in terms of non-interest expense and impaired loans. When we applied the equity multiplier indicator, the results support claims that Chinese owned banks is the least profitable amongst foreign owned and local owned banks.

The choices for China's banks future are therefore to continue expansion via merger and acquisition with overseas banks in Hong Kong. This is happening to a degree with European banks at present. The apparent advantages in terms of transferring technical and managerial efficiency gains to China's banks involved in M\&A with foreign banks appears to be the major advantage of such activities. In addition foreign banks operating in Hong Kong have added to their overall performance in their foreign operations in the fastest growing banking markets globally. 
Author Information: Xiaoxi Zhang is a doctoral student, Business School, University of Western Sydney, Australia: Email: xiaoxi.zhang@uws.edu.au; Phone: 610425408180 with Post address as Building 11, Campbelltown, Locked Bag 1797, Penrith, NSW, Australia 2751. Kevin Daly is an associate professor at the same university: Email: k.daly@uws.edu.au; Phone: 61246203546.

\section{References}

Berger, A N, and Udell G F., (2006). A more complete conceptual framework for SME finance. Journal of Banking \& Finance, , 30(11): 2945-2966.

Bourke, P., (1989). Concentration and other determinants of bank profitability in Europe, North America and Australia. Journal of Banking \& Finance, 1989, 13(1): 65-79.

Davis, K., and Lewis, M., (1982). Foreign banks and the financial system, Australian Financial System Inquiry. Commissioned Studies and Selected Papers. Part 1: Macroeconomic Policy: Internal Policy. Australian Government Publishing Service, Canberra.

Guru, B K, Vaithilingam, S., Ismail N., (2000). Electronic banking in Malaysia: a note on evolution of services and consumer reactions. Journal of Internet Banking and Commerce, 5(1): 234-256.

Guttentag, J, and Herring R., (1986). Disclosure policy and international banking. Journal of Banking \& Finance, 10(1): 75-97.

Herring, R. J., (199). Credit risk and financial instability. Oxford Review of Economic Policy, 15(3): 63-79.

Molyneux, P., Lloyd-Williams D. M., and Thornton, J., (1994). Competitive conditions in European banking. Journal of banking \& finance, 18(3): 445-459.

Petersen, M. A., Rajan, R. G., (1994). The effect of credit market competition on lending relationships. National Bureau of Economic Research.

Rhoades, S., (1998). The efficiency effects of bank mergers: An overview of case studies in nine mergers. Journal of Banking and Finance, 22 (3), 273 - 291.

Ruckes, M., (2004). Bank competition and credit standards. Review of Financial Studies, 17(4): 1073-1102.

Salas, V., Saurina, J., (2002). Credit risk in two institutional regimes: Spanish commercial and savings banks. Journal of Financial Services Research, 22(3): 203-224.

Samad, A., and Hassan, M. K., (2000). The performance of Malaysian Islamic bank during 1984-1997: an exploratory study. Thoughts on Economics, 10(1-2): 7-26.

Short, B. K., (1978). The relation between commercial bank profit rates and banking concentration in Canada, Western Europe, and Japan. Journal of Banking \& Finance, 3(3): 209-219. 